\title{
Developing a Forest Management Plan (DFMP) for Gatsibo District in the Eastern Province of Rwanda
}

\author{
Felix Rurangwa1, Mwangi James Kinyanjui'2, Frederick Bazimaziki', Jacques Peeters ${ }^{3}$, \\ Anicet Munyehirwe', Francis Musoke5, Gaspard Nelson Habiyaremye ${ }^{6}$, \\ Dismas Bakundukize ${ }^{1}$, Prime Ngabonziza' ${ }^{1}$, Jost Uwase ${ }^{4}$ \\ ${ }^{1}$ Rwanda Water and Forestry Authority (RWFA), Kigali, Rwanda \\ ${ }^{2}$ Department of Natural Resources, Karatina University, Karatina, Kenya \\ ${ }^{3}$ Belgian Technical Cooperation, Kigali, Rwanda \\ ${ }^{4}$ Inclusive Business and Consultancy (IB \& C Ltd.), Kigali, Rwanda \\ ${ }^{5}$ The International Union for Conservation of Nature (Forest Landscape Restoration, Kigali Office), Kigali, Rwanda \\ ${ }^{6}$ Rwanda Land Management and Use Authority, Kigali, Rwanda \\ Email: mwangikinyanjui@gmail.com
}

How to cite this paper: Rurangwa, F., Kinyanjui, M. J., Bazimaziki, F., Peeters, J., Munyehirwe, A., Musoke, F., Habiyaremye, G. N., Bakundukize, D., Ngabonziza, P., \& Uwase, J. (2018). Developing a Forest Management Plan (DFMP) for Gatsibo District in the Eastern Province of Rwanda. Open Journal of Forestry, 8, 247-265 https://doi.org/10.4236/ojf.2018.82017

Received: September 15, 2017

Accepted: April 24, 2018

Published: April 27, 2018

Copyright (c) 2018 by authors and Scientific Research Publishing Inc. This work is licensed under the Creative Commons Attribution International License (CC BY 4.0).

http://creativecommons.org/licenses/by/4.0/

\section{(c) () Open Access}

\begin{abstract}
In support of conservation of its fragile land resource, the government of Rwanda has proposed the management of all forests in the country under a specific management plan. This assignment sought to develop a management plan for the public productive forests of Gatsibo District in Eastern province of Rwanda. Data was collected from 1468 plots, proportionally allocated by size to the 375 forest stands. Information about the forest (qualitative data) was recorded and then forest measurements (inventory) done in a concentric cycle of $9.77 \mathrm{~m}$ and $3.99 \mathrm{~m}$ radius and all data recorded in a digital format using the survey CTO platform. The data was summarized and analyzed in a harmonized forest management tool for Rwanda comprising of six interlinked excel files based on Rwanda's silvicultural regimes and treatments. This analysis resulted to planning for silvicultural activities in each forest up to the year 2070. Results show that the public plantation forests of Gatsibo are poorly stocked mainly due to poor management and the best stocked forest had a basal area of only $13.3 \mathrm{~m}^{2} / \mathrm{ha}$. This implied low forest volumes for each of the wood requirements; timber wood, service wood and energy wood. Eucalyptus forests are the most common but are poorly stocked compared to the Pinus patula forests which are even aged by plantation. A projection of stocks shows that the forests can be sustained with an average wood volume of $73 \mathrm{~m}^{3} / \mathrm{ha}$, to provide harvests yearly and reduce the wood supply and demand gap in the district. A viability analysis indicates that some forests are viable for leasing
\end{abstract}


with good profits in the short term (10 years) and full term planning (40 years). However, some forests may not be commercially viable due to their current stocks and agro bioclimatic conditions, and these would be rehabilitated for ecosystem services. This plan supports the restoration of the forests of Gatsibo district through provision of specific guidelines for the management of the forests.

\section{Keywords}

Forest, Management, Planning

\section{Introduction}

\subsection{Background}

Arising from the effects of the 1994 Genocide, Rwanda has made tactical decisions on the management of its fragile natural resources including forests. The country's high population density estimated at 490 persons per $\mathrm{km}^{2}$ (Clay \& Lewis, 2017), exerts pressure on the highly fragile land resource where agriculture and forestry compete for the limited land comprising of easily eroded soils on steep topography (Roose \& Ndayizigiye, 1997). Towards strengthening forest governance as stipulated in the forest law, and meeting its economic development and poverty reduction strategy, the government of Rwanda seeks to enhance biodiversity in natural forests, ensure well stocked and sustained plantation forests and an overall increase in forest cover beyond 30\% (GoR, 2012).

One of the problems affecting the forest sector in Rwanda is the wide gap between wood demand and wood supply and this is associated to the poor stocking of plantation and productive forests due to poor management (Rudi et al., 2013). The Districts are the management implementation units for all government plans, hence the need to develop district forest management plans (DFMPs). As a solution to this problem, the government of Rwanda has prioritized management of all productive forests under a management plan and the first unit of operation is the District.

According to Randall (2007), a forest management plan refers to guidelines and actions that allow sustainable forest use. This results to a healthy and vigorous forest whose supply of products and amenities extends far into the future without compromising the current state of the forest. A good plan combines the natural and geographic characteristics of a woodlot with the interests and objectives of the forest manager. Kinyanjui (2009) explained that in developing a management plan, qualitative and quantitative information about the forest is needed. Qualitative information about a forest includes geographical location, size, the environment around the forest including levels of human interaction, topography, planting dates and soils. Quantitative information shows the forest and tree characteristics and requires undertaking an inventory of the forest. $\mathrm{Qu}-$ alitative and quantitative information is used to plan a sustained productivity of 
the forest based on the dynamics, demands and priorities of the people.

\subsection{The Forests of Rwanda}

Rwanda has a clear definition of forests which allows management and monitoring of the forests (MINIRENA, 2012). A forest refers to a group of trees higher than $7 \mathrm{~m}$ and a canopy cover of more than $10 \%$, or trees able to reach these thresholds in situ on a land of about 0.25 ha or more. This definition was used to categorise the forests of the country using high resolution Imagery (GoR, 2012) that showed a forest cover of $29 \%$ of the total land area. Natural forests which are largely managed for protection and biodiversity purposes comprise of Closed and degraded Natural Forests, Wooded Savannah, Bamboo Stands and Shrublands. The shrublands and closed natural forest comprise the largest proportion of these forests with $38.7 \%$ and $18 \%$ respectively of the total forest area. It is however noted that among the most encroached forests are the shrublands which are actively being converted into farmlands and are a major source of biomass energy (MINIRENA, 2014). The plantation forests managed for productive purposes comprise $42.5 \%$ of all the forests in the country and mainly comprise various species of Eucalyptus. Other species that occur in traces include Pinus patula, Callitris robusta, Cuppressus lusitanica, Grevillea robusta, Jacaranda mimosifolia, Alnus acuminata, Acacia mearnsii, Acacia melanoxylon and Maesopsis eminii.

Agro bio climatic zonation classifies forest productivity into 18 zones but this is generalized into three altitudinal zones; low (less than $1500 \mathrm{~m}$ ), medium (1500 $\mathrm{m}-1900 \mathrm{~m}$ ) and high (more than $1900 \mathrm{~m}$ ) (MINIRENA, 2014). The high altitude zones are mainly in the western side of the country while the low altitude zones are found in the eastern side of the country. Besides, classification by species and agro bioclimatic zones, the forests of Rwanda are classified by Management Entities (ME) which are defined as land areas with tree resources, where specific operational objectives (management, production or protection) are defined and where technical prescriptions to be followed for management are set or recommended (RWFA, 2017). These production objectives determine the Silvicultural/management operations/prescriptions to be done in the forest. There are a total of 8 management entities and the main ones found in public plantation forests are energy wood, service wood and saw timber management entities. In addition, the forests of Rwanda are classified by tenure as either public or private. Public forests are government forests but these are either managed by the State or by the Districts.

Guided by the forest policy, which identified that public plantation forests are poorly managed but offer a potential for a sustained productivity, the government of Rwanda seeks to create Forest Management Units (FMUs) which are clearly delimited areas that comprise forests with different production objectives and tree species and which constitute economic units to be exploited or managed sustainably by an economic actor. These units are envisaged for lease to 
private operators or local cooperatives who will manage the forests on long term contracting basis on a public-private -partnerships arrangement. Each FMU is further divided into sub groups to allow the spreading of implementation and silvicultural activities over a number of years to create a rotation cycle (Tahvonen \& Salo, 1999).

This assignment sought to develop a management plan for the public productive forests of Gatsibo district in the Eastern province of Rwanda, to support the sustainable management of the forests in an attempt to bridge the supply and demand gap for wood products. This supports the overall goal of economic development and poverty reduction. Specifically the assignment 1) collated forest resource data to show the stocking of the forests 2) created management units for leasing 3 ) analyzed the viability of the management units in the short (10 years) and long (more than 40 years) term planning.

\section{Methods}

\subsection{Study Area}

Gatsibo District with an area of 158,405 ha is in the Eastern Province of Rwanda and is divided into 14 Administrative Sectors (imirenge): Gasange, Gatsibo, Gitoki, Kabarore, Kageyo, Kiramuruzi, Kiziguro, Muhura, Murambi, Ngarama, Nyagihanga, Remera, Rugarama and Rwimbogo. The district lies at about latitude $1^{\circ} 27^{\prime} 30^{\prime \prime}$ and $1^{\circ} 52^{\prime} 50^{\prime \prime}$ South and longitude $30^{\circ} 09^{\prime} 42^{\prime \prime}$ and $30^{\circ} 50^{\prime} 20^{\prime \prime}$ East. A vast area of the district comprises of shrublands in Gabiro military scheme and Akagera National Park. Gatsibo District has a hydrographic network composed of several wetlands whose total area is 17,300 ha. The largest continuous wetlands are found in Akagera National Park and include Akagera River and Lake Milindi. The Topography is characterized by lowly inclined hills and dry valleys. The District experiences low rainfall $(830 \mathrm{~mm} / \mathrm{yr})$ and high temperatures in two main seasons. The dry season extends 5 months with an annual average temperature of $25.3^{\circ} \mathrm{C}-27.7^{\circ} \mathrm{C}$. The 2012 mapping (GoR, 2012) identified 9780 ha of plantation forests in the district of which 8380 ha comprise of Eucalyptus spp. The public forest cadaster indicated a total of 6175 ha in a total of 375 stands of public forests. A total of 5609 ha are state forests and 565 ha are district tenure forests.

\subsection{Sampling Allocations}

Due to the unique characteristics of the forests which appear in small isolated patches a proportional allocation sampling scheme (Table 1) was adopted to balance between forests stand size and representation of all forest stands resulting to 1468 sample plots. The GPS coordinates of each plot were uploaded into data collection tablets using MapIt GIS software. In this tablet, the approved data collection tool/questionnaire which had been programmed in the SurveyCTO platform was also loaded to allow collection of both qualitative and quantitative/inventory information about the sample plot. Qualitative information 
Table 1. The sampling scheme based on forest stand area.

\begin{tabular}{|c|c|c|c|c|c|c|c|}
\hline \multirow[b]{2}{*}{ Area classes } & \multicolumn{2}{|c|}{ State forests } & \multicolumn{2}{|c|}{ District forests } & \multicolumn{2}{|c|}{ Total } & \multirow[b]{2}{*}{ Sample plots } \\
\hline & $\begin{array}{l}\text { No. of } \\
\text { forests }\end{array}$ & Area (ha) & $\begin{array}{l}\text { No. of } \\
\text { forests } r\end{array}$ & $\begin{array}{l}\text { Area } \\
\text { (ha) }\end{array}$ & $\begin{array}{l}\text { No. of } \\
\text { forests }\end{array}$ & $\begin{array}{l}\text { Area } \\
\text { (ha) }\end{array}$ & \\
\hline Area $<0.5$ & 10 & 3.24 & 11 & 3.72 & 21 & 6.96 & 26 \\
\hline Area $\geq 0.5$ and $<1$ ha & 18 & 13.46 & 12 & 9.82 & 30 & 23.28 & 34 \\
\hline Area $\geq 1$ and $<5$ ha & 114 & 257.2 & 43 & 95.6 & 157 & 352.8 & 471 \\
\hline Area $\geq 5$ and $<12$ ha & 57 & 420.2 & 8 & 55.5 & 65 & 475.7 & 325 \\
\hline Area $\geq 12$ ha & 95 & 4915.5 & 7 & 400.5 & 102 & 5315.9 & 612 \\
\hline Total & 294 & 5609.6 & 81 & 565.11 & 375 & 6174.7 & 1468 \\
\hline
\end{tabular}

(date of planting, topography, forest cover, status of forest, soils, levels of human interaction etc.) targeted the general environment around a sample plot while quantitative information (tree species, number of trees, dbh sizes, tree heights etc.) were specifically collected for the sample plot. Ground data collected in the forest was submitted electronically from the sampling point directly to the servers in offices, and received by the coordination team allowing real-time monitoring of the field activities. Training on the use of the tablets for data collection and submission was done to the 15 teams of 15 enumerators.

A total of 72 plots were re-measured for quality control and analysis of variance on the diameter measurements used to confirm the accuracy of the original measurements.

The sample plot comprised two concentric cycles (Figure 1) measuring 9.77 $\mathrm{m}$ radius and $3.99 \mathrm{~m}$ radius. In the bigger plot, all trees greater than $5 \mathrm{~cm}$ Dbh were recorded per species, tree height for 3 trees (one closest to the center, tree with largest Dbh and tree with smallest Dbh). In the small plot, tree regeneration was recorded by counting saplings and seedlings per species. Tree diameters were measured by a steel diameter tape calibrated to $0.1 \mathrm{~cm}$ intervals and tree height was recorded by a suunto hypsometer.

\subsection{Calculation of Forest Volumes}

The Basal area for each tree was calculated as

$$
B A=\left(\pi D^{2}\right) / 40000
$$

where $B A=$ Basal area in $\mathrm{m}^{2}$;

$D=\mathrm{Dbh}$ (Tree diameter measured at $1.3 \mathrm{~m}$ height, referred to as Diameter at breast Height) in cm.

Plot data was converted into per hectare basis using the number of plots in the stand and a plot expansion factor based on the plot size (plot radius $=9.77 \mathrm{~m}$ ) to give number of trees or basal area per hectare. Forest volumes (above ground) were calculated per tree using allometric equations developed in the National forest inventory for the low altitude zones and the Eastern Province of Rwanda (Fonton \& Weingart, 2015) were used to calculate the volume of each tree 


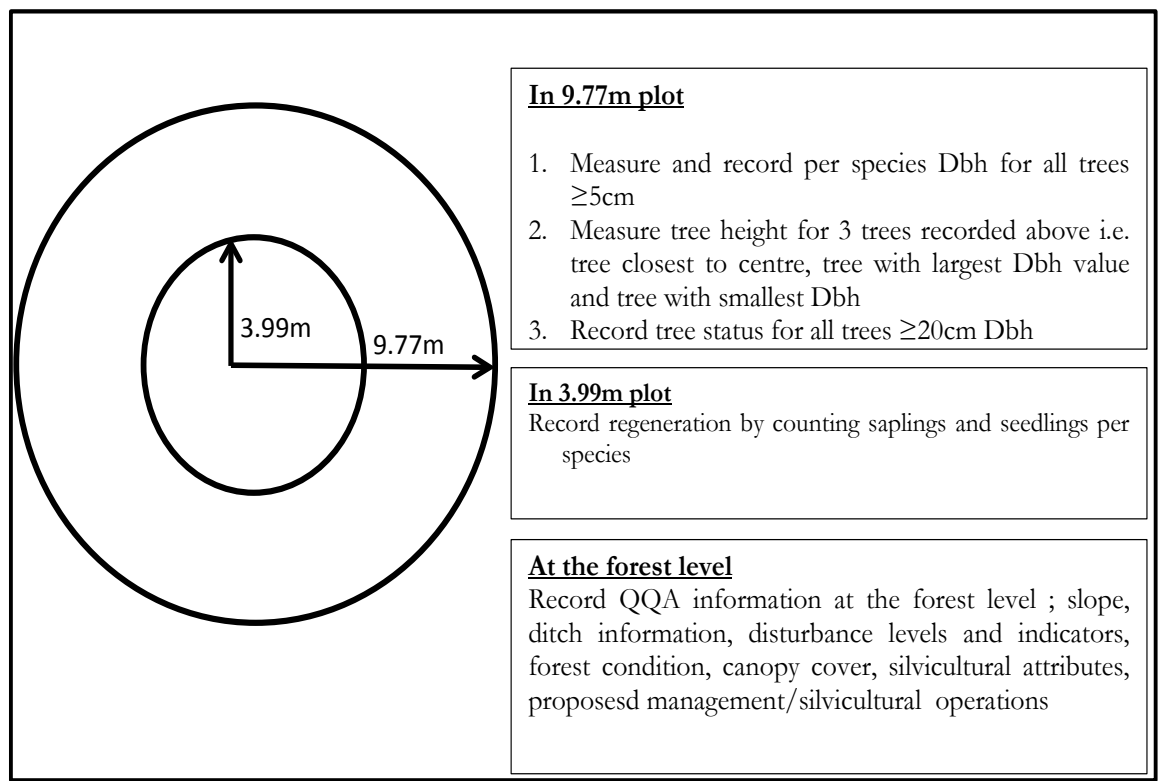

Figure 1. Concentric circular plots for data collection in TIF.

measured (Table 2). The total tree volume was separated into volumes for different uses $\left(V_{t i}=\right.$ Volume of saw timber, $V_{s}=$ Volume of service wood, $V_{e}=$ Volume of energy/fuel wood and $V_{t}=$ Total volume) based on an allocation formula approved by the Department of Forests and Nature Conservation of Rwanda (Table 3).

\subsection{Summarizing Plot Data}

The Department of Forestry has approved a harmonized tool for summarizing qualitative and quantitative data to allow a harmonized implementation of forest management plans in the country. The field data was summarized into these tools comprising of six excel files interlinked by formulas as illustrated below.

1) Table zero: (the QQA Table). It has one excel sheet and is the table where all Qualitative and Quantitative data collected in the field is entered per forest stand in a total of 52 attribute columns.

2) Table 1: (The Rwanda Silvicultural Treatment file). It is a summary of silvicultural Treatments done in Rwanda including tree species, their silvicultural treatments for different Management Entities, productivity under different site indices and the rotation cycles.

3) Table 2: (The Master planning file). This file has several sheets. Sheet one allows creation of Forest Management Units (FMUs) guided by administrative boundaries, creating subgroup FMUs for developing rotation cycles, proposing treatment regimes/treatment series for different plantations and proposing management entities to balance availability of wood products.

4) Table 3: (The Activity planning file). It gives a detailed information and also in summary, all silvicultural activities to be done per forest stand for the planning period 2017-2070. For example, it shows the number of seedlings to be 
Table 2. Allometric equations for Eucalyptus and Pine available for Gatsibo district.

\begin{tabular}{|c|c|c|c|}
\hline Species & Variables & Stand type & Equation for volume estimation \\
\hline Eucalyptus spp. & DBH & High Forest & $\operatorname{Exp}(-2.446+2.574 * \ln (D)) / 1000$ \\
\hline Eucalyptus spp. & $\mathrm{DBH}$ & Coppice & $\operatorname{Exp}(-2.703+2.67 \star \ln (D)) / 1000$ \\
\hline Eucalyptus spp. & DBH/Height & High Forest & $\operatorname{Exp}(-3.081+2.089 * \ln (D)+0.785 \ln (T H)) / 1000$ \\
\hline Eucalyptus spp. & DBH/Height & Coppice & $\operatorname{Exp}\left(-3.242+2007^{\star} \ln (D)+0.937^{\star} \ln (T H)\right) / 1000$ \\
\hline Pinus patula & $\mathrm{DBH}$ & High Forest & $\operatorname{Exp}\left(-1.765+2.384{ }^{\star} \ln (D)\right) / 1000$ \\
\hline Pinus patula & DBH/Height & High Forest & $\operatorname{Exp}(-2.958+2.016 * \ln (D)+0.847 * \ln (T H)) / 1000$ \\
\hline
\end{tabular}

Table 3. Allocation of wood volume to saw timber, service wood and energy wood from total tree volume.

\begin{tabular}{cccc}
\hline Dbh of tree & Volume saw timber & Volume service wood & Volume energy wood \\
\cline { 2 - 4 } & $\left(\mathrm{V}_{\mathrm{ti}}\right)$ & $\left(\mathrm{V}_{\mathrm{s}}\right)$ & $\left(\mathrm{V}_{\mathrm{e}}\right)$ \\
\hline $\mathrm{Dbh}>30 \mathrm{~cm}$ & $35 \%$ of $\mathrm{V}_{\mathrm{t}}$ of tree & 0 & $65 \%$ of $\mathrm{V}_{\mathrm{t}}$ of tree \\
$8 \mathrm{~cm} \geq \mathrm{Dbh}<30 \mathrm{~cm}$ & 0 & $50 \%$ of $\mathrm{V}_{\mathrm{t}}$ of tree & $50 \%$ of $\mathrm{V}_{\mathrm{t}}$ of tree \\
Dbh $<8 \mathrm{~cm}$ & 0 & 0 & $100 \%$ of $\mathrm{V}_{\mathrm{t}}$ of tree \\
\hline
\end{tabular}

planted for each forest stand per year either under total conversion or beating up, the number of hectares for thinning and pruning, weeding and ditch digging.

5) Table 4: (The harvesting calculations file). It gives detailed information and also in summary (per FMU) the stocking for each year projected to the year 2070. It also shows annual projections of thinning, pruning and harvest stocks for each forest in each year up to 2070.

6) Table 5: (The Action Plan and Budget). It gives a list of expected activities that will lead to the actualization of the management plan and the associated budget in the 10 year short term planning.

\subsection{Creation of FMUs}

Using the summarized data in the Excel files, FMUs were created separated by tenure (State or District). They were identified as a group of forests that can be economically managed as a unit and can be leased to a single contractor. A single FMU comprised forests in one sector but for sectors with small forest plantations, several adjacent sectors were combined to make an FMU. An FMU was created to contain different management entities to allow management of forests for production of different wood products (saw timber, service wood and energy wood) and this implies that different silvicultural operations can be carried out in the FMU. Each FMU was divided into subgroup FMUs which can form units for annual implementation of activities in an effort to develop a rotation cycle with specific activities for each year. The subgroup FMUs comprises forests in smaller units within an FMU e.g. a cell. In large forest blocks, Subgroup FMUs comprised the forest sections that are separated by physical features like rivers or 
Table 4. Statistics of forests based on forest size categories.

\begin{tabular}{ccccccc}
\hline $\begin{array}{c}\text { Category of } \\
\text { forest area }\end{array}$ & $\begin{array}{c}\text { No. of } \\
\text { forest } \\
\text { stands }\end{array}$ & $\begin{array}{c}\text { Area of } \\
\text { forests (ha) }\end{array}$ & $\begin{array}{c}\text { Mean basal } \\
\text { area }\left(\mathrm{m}^{2}\right)\end{array}$ & $\begin{array}{c}\text { Standard } \\
\text { deviation }\end{array}$ & $\begin{array}{c}\text { Coefficient of } \\
\text { variation (\%) } \\
\text { of Dbh }\end{array}$ & $\begin{array}{c}\text { Standard error } \\
\text { of Dbh } \\
\text { estimate }\end{array}$ \\
\hline $\begin{array}{c}\text { Area }>0.25 \\
\text { but }<1 \text { ha }\end{array}$ & 58 & 30.24 & 5.42 & 6.81 & 125.72 & 0.72 \\
Area $1-5$ ha & 155 & 352.82 & 6.96 & 7.04 & 101.15 & 0.56 \\
Area $5-12$ ha & 63 & 475.66 & 9.26 & 7.55 & 81.56 & 1.17 \\
Area $>12$ ha & 100 & 5351.97 & 13.30 & 7.52 & 56.57 & 1.33 \\
\hline
\end{tabular}

Table 5. The summary of volumes for different uses in the District.

\begin{tabular}{|c|c|c|c|c|c|c|c|}
\hline Species & $\begin{array}{l}\text { No of } \\
\text { stands }\end{array}$ & Area (ha) & $\begin{array}{c}\text { Basal } \\
\text { area } \\
\mathrm{ha}^{-1}\left(\mathrm{~m}^{2}\right)\end{array}$ & $\begin{array}{l}\text { Vti.ha }{ }^{-1} \\
\left(\mathrm{~m}^{3}\right)\end{array}$ & $\begin{array}{c}\text { Vs } \cdot h a^{-1} \\
\left(\mathrm{~m}^{3}\right)\end{array}$ & $\begin{array}{l}\text { Ve.ha }{ }^{-1} \\
\left(\mathrm{~m}^{3}\right)\end{array}$ & $\begin{array}{c}\text { Tree } \cdot \text { Vol } \cdot \text { ha }^{-1} \\
\left(\mathrm{~m}^{3}\right)\end{array}$ \\
\hline Eucalyptus spp & 299 & 4573.77 & 7.44 & 7.71 & 16.15 & 31.26 & 54.94 \\
\hline Pinus patula & 51 & 1009.04 & 15.44 & 17.80 & 37.55 & 69.33 & 124.69 \\
\hline Calitris robusta & 3 & 79.91 & 12.79 & 5.98 & 23.82 & 31.30 & 61.10 \\
\hline $\begin{array}{c}\text { Cuppressus } \\
\text { Iusitanica }\end{array}$ & 1 & 0.39 & 0.07 & - & - & 0.18 & 0.18 \\
\hline $\begin{array}{c}\text { Casuarina } \\
\text { equisetifolia }\end{array}$ & 1 & 1.29 & 18.32 & 26.25 & 41.44 & 45.59 & 113.29 \\
\hline Grevillea robusta & 3 & 2.04 & 15.07 & 12.28 & 46.66 & 63.42 & 122.35 \\
\hline Mixed species & 16 & 499.58 & 11.66 & 10.48 & 21.46 & 48.60 & 80.54 \\
\hline No trees & 1 & 8.67 & & & & & \\
\hline
\end{tabular}

roads. In each FMU, two treatment series were considered (conversion or management of the forest) depending on the nature of the forest during the assessment.

\subsection{Financial Balancing}

Every investment should be analyzed for profitability (Slater \& Narver, 2000). In this case, the FMUs have been created for leasing to private investors. Based on the volume of wood available and the productivity potential, a financial balance allows the private investor to analyze the viability of the project. This allows the government creates incentives in non-viable forests to meet other non-financial conservation objectives. In doing a financial balance, the following considerations were made:

1) The excel files show the yearly harvests (thinning, pruning and harvesting) per forest and per FMU over the short term (10 years) and the full rotation cycle (40 years);

2) There is an estimated cost of producing $1 \mathrm{~m}^{3}$ of wood by the government which is currently equal to 11,000 RWF. This was taken as the minimum price of the wood which would give an investor some returns;

3) It was also estimated that the contractor will incur some cost of raising seedlings and managing the plantations as follows: 
a) The cost of raising 1 seedling was 5 RWF (as a subsidy from the central government);

b) The cost of planting and beating up was 4000,000 RWF per ha;

c) The cost of thinning and pruning was 50,000 RWF per ha;

d) The cost of ditch digging and management was 250,000 RWF per ha;

e) The cost of weeding and firewall management was 150,000 per ha;

f) Apart from these costs, it was estimated that the cost of supervision, and maintenance of equipment can double the costs summed above.

A financial balance compared accumulated income (in a specific year of management plan implementation) from the sale of wood harvested at a unit price of 11,000 RWF versus the accumulated cost (in a specific year of implementation) of silvicultural activities as described above.

Three scenarios were envisaged as follows:

1) The best case scenario where the plan is actualized as projected in the excel files. This is perfect implementation of the management plan with $100 \%$ of the proposed harvests attained in each year of the full rotation cycle.

2) Real world scenario assumes a $75 \%$ efficiency of returns from harvests in each year of the full rotation cycle. This could be attributed to effects of climate change, fluctuating global economy and the fact that human activities on the forest can reduce actualization of the targeted benefits.

3) The worst case scenario assumed a $25 \%$ efficiency of returns from harvests in each year of the rotation cycle. This could be attributed to failure to resolve disputes concerning forests, full effect of natural calamities and total negligence by mangers among other causes.

\section{Results and Discussion}

\subsection{The General Status of the Forests}

The public forests of Gatsibo District comprise of a variety of species dominated by Eucalyptus spp. There were 300, Eucalyptus spp stands (4620 ha) and 51 Pinus patula stands (1009 ha). The other species comprise of a few stands either isolated or in mixtures. Among the sectors, Gitoki has the biggest forest area (1305 ha in 34 stands) then Rugarama sector (969 ha in 28 stands) and Nyagihanga (866 ha in 46 stands). Muhura sector has 37 forest stands comprising of small forests (total of $121 \mathrm{ha}$ ). Table 4 shows that small sized forest stands were generally low stocked (basal area $=5.42 \mathrm{~m}^{2}$ ) and also had high variability of stocking with a CV of Dbh equal to 125.72 . In such a case so many sample plots are required to confirm the accuracy of the data collected (Cornelius, 1994). The stocking improves as the forest sizes increases and in forest greater than 12 ha, the basal area average is $13.30 \mathrm{~m}^{2}$. The increase in forest area also enhances the reliability of the results as the $\mathrm{CV}$ of Dbh decreases to an acceptable value of 56.57 .

A mean basal area of $13.30 \mathrm{~m}^{2}$ is relatively low. Kinyanjui (2009) noted that at a basal area of $17 \mathrm{~m}^{2}$, the Mau forest of Kenya was recorded as poorly stocked. This therefore implies that, the best stocked plantations of Gatsibo district are 
very poorly stocked. This could be attributed to the climatic conditions of the district noting that this is the relatively dry zone of Rwanda. However, the field findings illustrated poor management of the plantations as the main cause of poor stocking.

The categorisation of results by species (Table 5) shows that the eucalyptus forest stands though occupying the largest area (4574 ha) have poor stocking with an average of $7.44 \mathrm{~m}^{2}$ basal area and this implies low volumes of wood per hectare. Due to their large area in the district, these Eucalyptus forest stands can provide $35,247 \mathrm{~m}^{3}$ of timber volume, $73,882 \mathrm{~m}^{3}$ of service wood volume and $142,989 \mathrm{~m}^{3}$ of energy wood volume. The Pinus patula forests are well stocked with $15.44 \mathrm{~m}^{2}$ basal area and a total wood volume of $124.69 \mathrm{~m}^{3}$ per hectare. These forests also have a better timber volume at $17.8 \mathrm{~m}^{3}$ per hectare. Due to their good stocking, the Pinus patula forests are a good source of wood products with ability to provide $17,964 \mathrm{~m}^{3}$ of timber, $37,894 \mathrm{~m}^{3}$ of service wood and $69,958 \mathrm{~m}^{3}$ of energy wood. Though the Casuarina equisetifolia forests indicate the best stocking with a basal area of $18.32 \mathrm{~m}^{2}$, only one such pure forest was identified and had an area of only 1.29 ha.

The illustration of poor stocking which indicates that the best stocked forests (Pinus patula) had an average of $124.69 \mathrm{~m}^{3}$ of above ground volume is low for a plantation forest managed for productive purposes. Nyirambangutse et al. (2017) gave an above ground stocking of $185.76 \mathrm{MgC} \cdot \mathrm{ha}^{-1}$ for late successional natural forests of Nyungwe tropical montane rainforest located in south-western Rwanda, which is more than double the carbon content of the best stocked public plantation forest of Gatsibo district (noting the biomass expansion factor and the carbon content in each unit of wood).

Figure 2 shows the distribution of forest volumes $(\mathrm{Vt})$ among tree diameter sizes in the District. The curve is skewed to the small diameter sizes showing that the forests comprise of many small sized trees. The forest planting dates ranged from 1940s to 2015 indicating that small sized trees in the forests are not necessarily due to age but mainly attributed to poor management. There were many degraded and poorly managed forests which do not grow to big sizes and this reduces the potential of the forests to provide products to the users. Some eucalyptus forests managed under coppice systems do not grow to big sizes but some of the coppice systems were found to be overgrown beyond the 4 cycles limit indicated in the Rwanda silvicultural planning (Excel file 1).

Among human activities that may be attributed to the reduced productivity of the forests are illegal cutting, harvesting plant parts, fire, farming. Some forests were recorded as having conflicts of ownership making lease arrangement difficult. In addition, aphids (Thaumastocoris peregrinus) are common in some eucalyptus plantations and lower the productivity of the forests.

\subsection{Projections of Harvests}

A projection of the existing stock (Figure 3) indicates that there were $677,559 \mathrm{~m}^{3}$ of standing wood volume in the District at the beginning of the planning period 


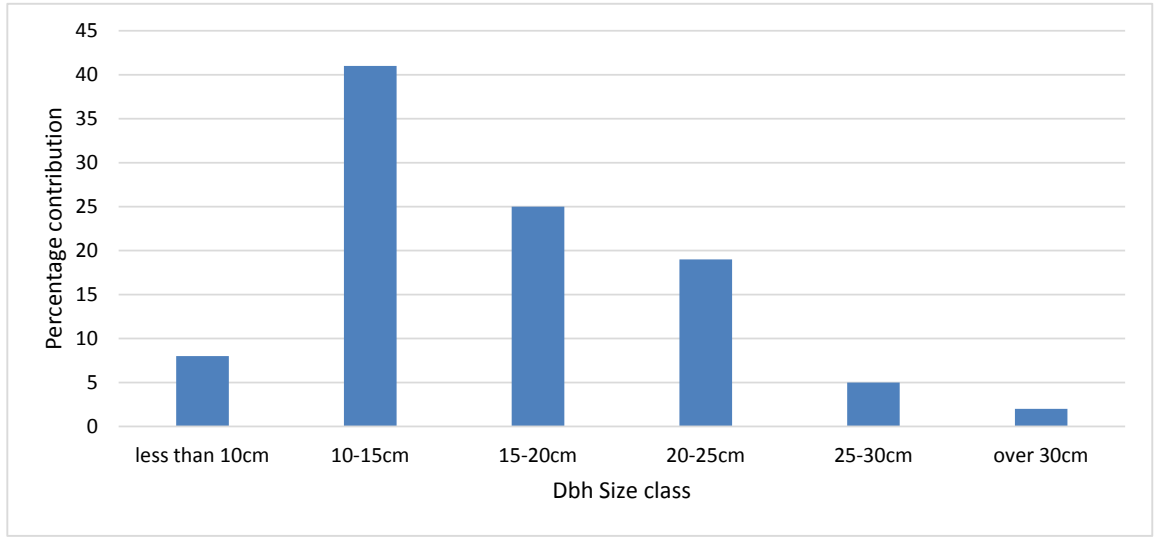

Figure 2. A comparison of total wood volume by diameter size classes.

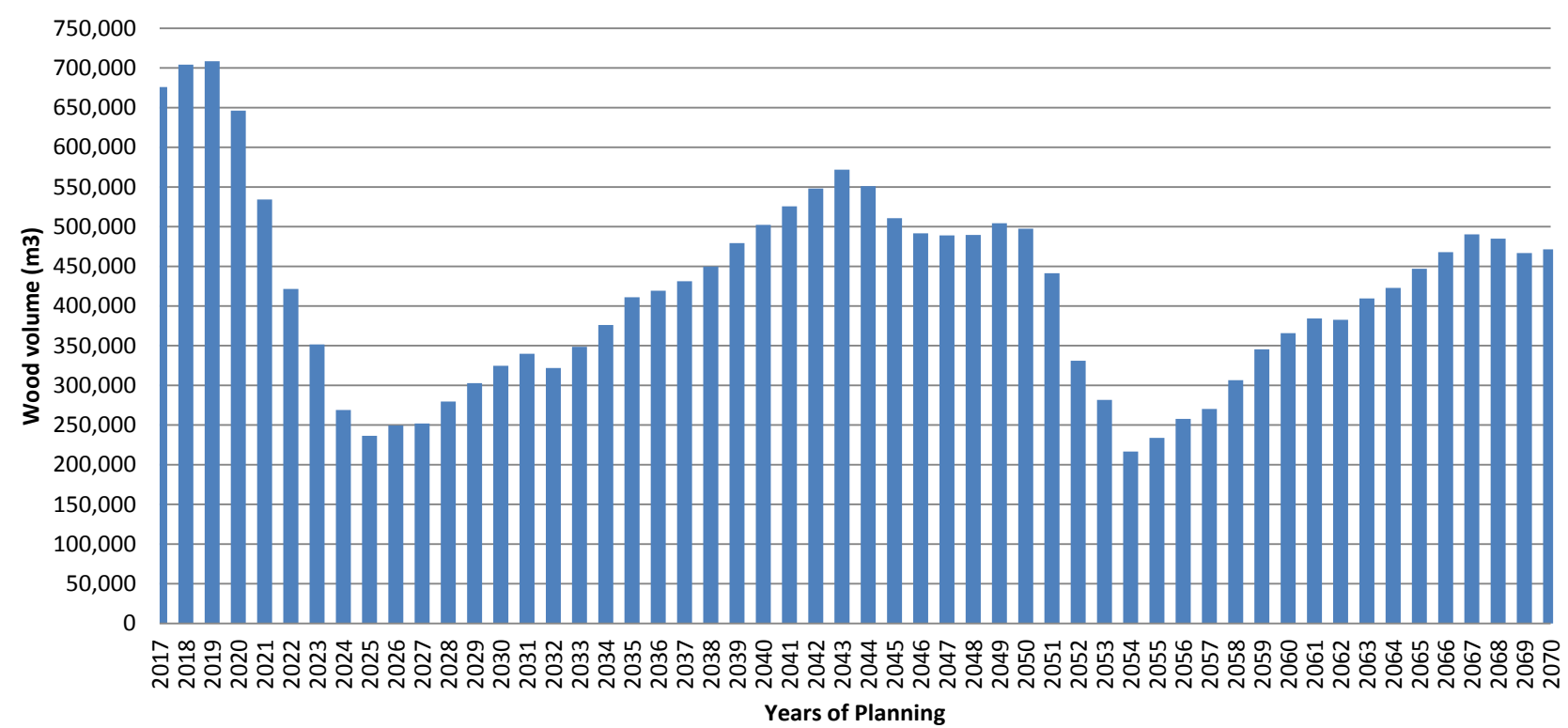

Figure 3. Standing stock $\left(\mathrm{m}^{3}\right)$ projection for all public forests in the District (2017-2070).

(2017). There was a slight increase in 2018 and 2019 based on the planning for conversions followed by yearly harvests in 2019 up 2025 that keep on reducing the stock. A slight build-up follows in 2026 due to the volumes of the recently planted trees. The figure illustrates a sustained productive forest up to the year 2070 which allows the forest to continuously provide forest products without compromising their status (Sharma \& Henriques, 2005).

From Figure 3, the average stock of the forests in the district for all years up to 2070 is $450,000 \mathrm{~m}^{3}$ which implies maintaining about $73 \mathrm{~m}^{3}$ of wood volume for each of the 6175 ha over the whole rotation cycle. The low volume is attributed to the big proportion of forests that will be managed under coppice treatment regimes in the Eucalyptus forests. These coppicing management systems will last 4 cycles of 8 years each and will provide energy wood and service wood.

The projection for harvestable stock from full cutting and Coppice Cutting (Figure 4) shows that major harvests start in 2019 with a wood volume of 88,183 $\mathrm{m}^{3}$ and this is followed by several other major harvests up to year 2025. In total 


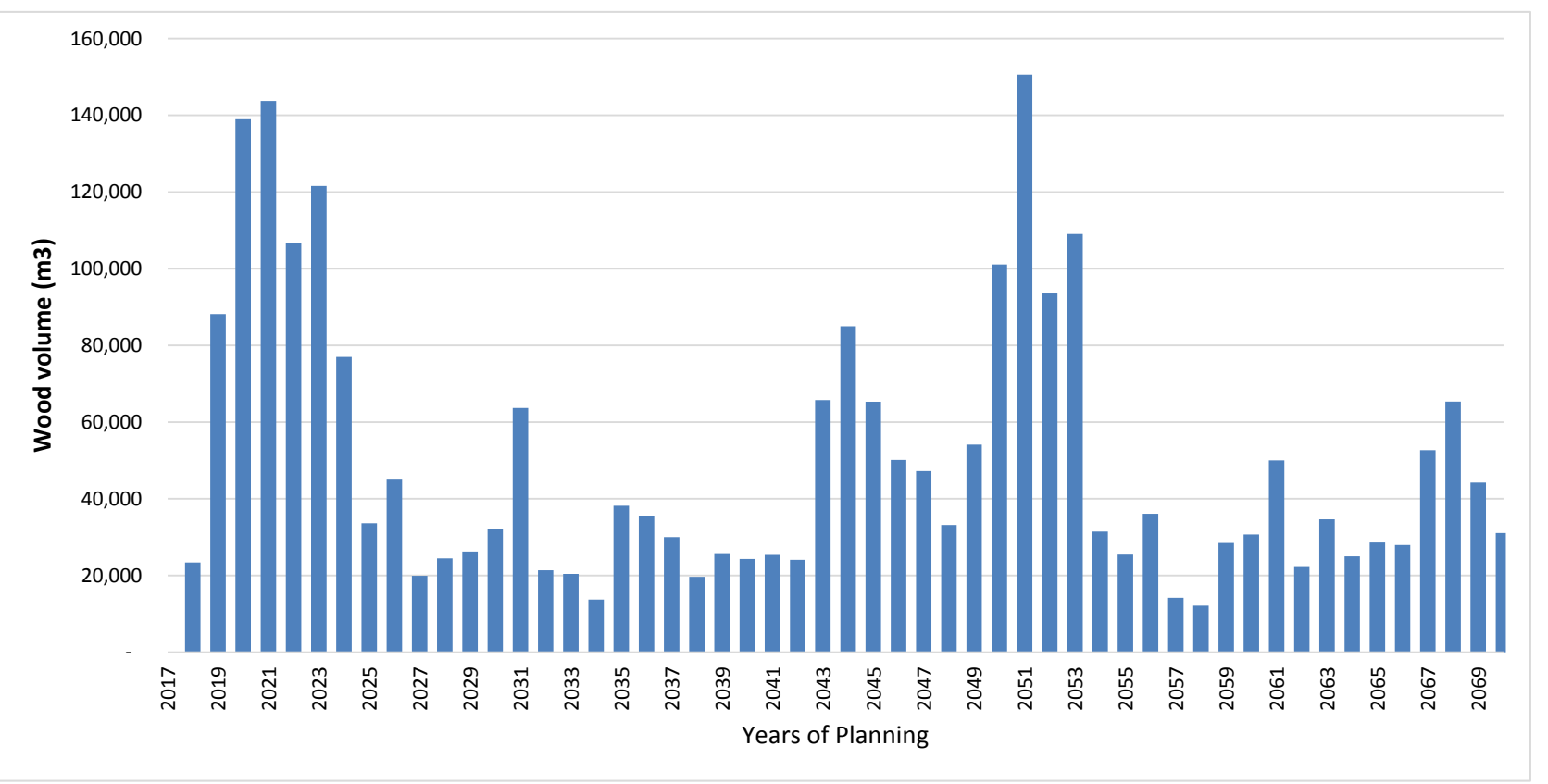

Figure 4. A sustainable harvest in the long-term planning period (2017-2070).

there will be harvests of about 780,000 $\mathrm{m}^{3}$ of wood from public plantations by the year 2027 in the whole district. The harvests illustrate the availability of wood products over the entire planning period. Drigo et al. (2013) illustrated that the district has a wood deficit of $40,000 \mathrm{~m}^{3}$ and this can be reduced to only $2500 \mathrm{~m}^{3}$ if this management plan is efficiently implemented.

\subsection{Forest Management Units}

A total of 21 Forest Management Units (FMUs) were created for the District, of which 3 belong to the district (Table 6 and Figure 5) and 18 belong to the state (Table 7 and Figure 5 and Figure 6). Most of the FMUS abide to the average 200 ha proposed by the government to allow local communities and cooperatives participate in forest management. However, state FMU1 had 661.82 ha due to a special request to manage the Pinus patula forests of Gitoki sector as a single unit. Some FMUs are confined to small administrative areas (e.g. District FMU2 in Rugarama sector, state FMU1 in Gitoki sector and state FMU6 in Rwimbogo sector) making their administration easy. However, there are FMUs in which forests are scattered across many administrative sectors (e.g. District FMU3) making their management difficult.

Some of the plantations were recorded as very old. For example in State FMU 18 , the forests have an average of 75 years which shows a long history of poor or no management. This is replicated in many forests which have gone beyond the full 40 year rotation cycle without harvesting. Such forests also include forests in State FMUs 13, 14, 15, 16 and 17. In such cases, an immediate harvesting will be required so that planting can be done and a sustainable harvesting cycle implemented as proposed in this plan. 
Table 6. District tenure FMUs with their administrative units.

\begin{tabular}{clccc}
\hline District FMU & \multicolumn{1}{c}{ Administrative unit } & Total area (ha) & $\begin{array}{c}\text { No. of } \\
\text { stands }\end{array}$ & $\begin{array}{c}\text { Average tree } \\
\text { age (yrs.) }\end{array}$ \\
\hline 1 & Gatsibo, Ngarama, Nyagihanga sectors & 210.99 & 26 & 36 \\
2 & $\begin{array}{l}\text { Rugarama sector } \\
\text { Rwimbogo, Kabarore, Gitoki, Kageyo, }\end{array}$ & 208.55 & 6 & 17 \\
\multirow{2}{*}{ Total } & $\begin{array}{l}\text { Remera, Kiziguro, Gasange, Kiramuruzi, } \\
\text { Kiziguro, MurambiMuhura, sectors }\end{array}$ & 146.17 & 54 & 29 \\
\hline
\end{tabular}

Table 7. State tenure FMUs with their administrative units.

\begin{tabular}{|c|c|c|c|c|}
\hline $\begin{array}{l}\text { State } \\
\text { FMUs }\end{array}$ & Administrative unit & $\begin{array}{c}\text { Total } \\
\text { area (ha) }\end{array}$ & $\begin{array}{l}\text { No. of } \\
\text { stands }\end{array}$ & $\begin{array}{c}\text { Average } \\
\text { tree age } \\
\text { (yrs.) }\end{array}$ \\
\hline 1 & Gitoki Sector (Pines) & 661.82 & 18 & 33 \\
\hline 2 & Gatsibo and Kageyo; Sectors (Pines) & 296.28 & 15 & 33 \\
\hline 3 & Nyagihanga Sector (Kibare, Murambi and Nyagitabire Cells) & 375.06 & 15 & 39 \\
\hline 4 & Nyagihanga Sector (Gitinda, Nyamirama and Mayange Cells) & 369.79 & 20 & 34 \\
\hline 5 & Ngarama and Kabarore Sectors & 207.79 & 28 & 17 \\
\hline 6 & Rwimbogo Sector & 449.19 & 25 & 24 \\
\hline 7 & Gatsibo Sector (other species) & 208.28 & 17 & 47 \\
\hline 8 & Gitoki Sector (Bukomane, Cyabusheshe and Nyamirama Cells) & 291.49 & 18 & 25 \\
\hline 9 & Gitoki Sector (Rubira, Mpondwa and Karubungo Cells) & 349.47 & 5 & 27 \\
\hline 10 & Kageyo Sector (Busetsa Cell) & 345.75 & 7 & 31 \\
\hline 11 & Kageyo Sector (Kintu, Nyagisozi and Gituza Cells) & 337.82 & 26 & 30 \\
\hline 12 & Remera Sector & 271.22 & 6 & 32 \\
\hline 13 & Rugarama Sector (Matare Cell) & 271.14 & 4 & 48 \\
\hline 14 & Rugarama sector (Kanyangese and Matunguru Cells) & 404.50 & 8 & 41 \\
\hline 15 & Bugarama Sector (Gihuta, Bugarama and Remera Cells) & 88.40 & 14 & 43 \\
\hline 16 & Kiziguro Sector & 348.46 & 14 & 50 \\
\hline 17 & Kiramuruzi and Murambi Sectors & 163.61 & 42 & 44 \\
\hline 18 & Gasange and Muhura Sectors & 170.28 & 32 & 75 \\
\hline Total & & 5610 & 314 & \\
\hline
\end{tabular}

The management units will ease management of the forests within them noting that the specific silvicultural operations have been proposed for each forest. The management unit is a viable entity that allows exploitation of a sizeable forest resource. The size of the management unit and its administrative delimitations allow local players including communities to participate in forest conservation which motivates them and provides a platform for them to improve their family income and is in line with the government development programes (GoR, 2017). This plan proposes to immediately avail the 21 forest management units 


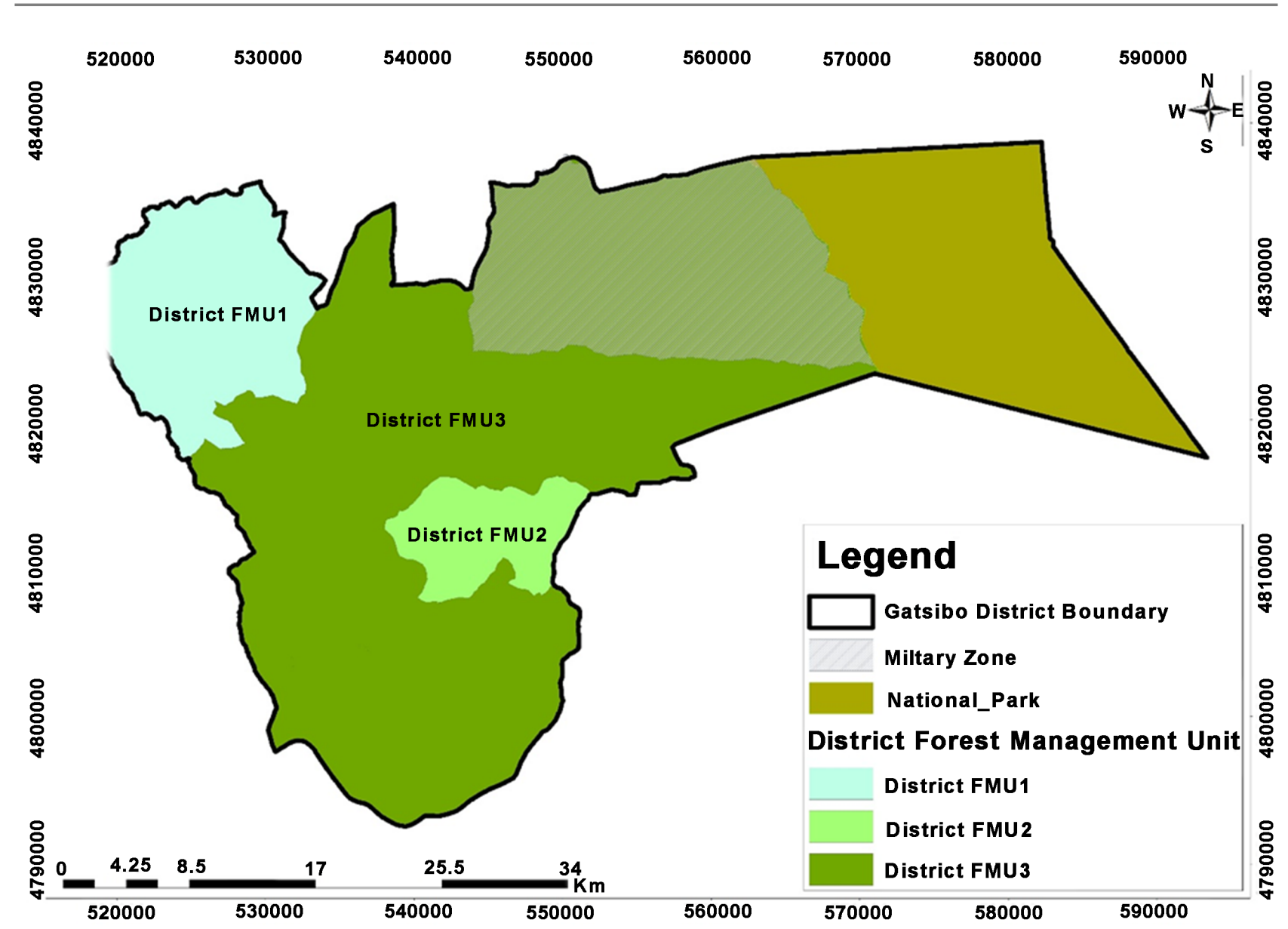

Figure 5. Distribution of district forest management units in gatsibo district.

for leasing to allow an immediate implementation of the forest restoration programmes.

\subsection{Financial Viability of the Management Units}

Results of viability analysis indicated that most of the FMUs are viable for leasing and provide returns in the short term (10 years) and long term (40 years) planning. In terms of financial returns, state FMU1 has the highest returns in the short term and in the long term (Table 8). In this FMU comprising of Pine forests, the medium case scenario also gives high returns as compared to the other FMUs. The main reason for the high returns in state FMU1 is its large area. However, since this FMU is found within a single administrative unit (Gitoki sector), it makes management easy.

The other FMUS with good returns as shown in Table 8 are state FMU2 (Pine forests), State FMU3 (Eucalyptus forests), State FMU4 (Eucalyptus forests), State FMU10 (Eucalyptus forests), state FMU11 (Eucalyptus forests) and state FMU12 (Eucalyptus forests). These are the FMUs that have a lot of harvests in the early years of implementation of the plan and would be very attractive to the private investors. It was noted that in all FMUs, the worst case scenario gives negative returns in the 40 year full rotation cycle. This implies that poor management of 
F. Rurangwa et al.

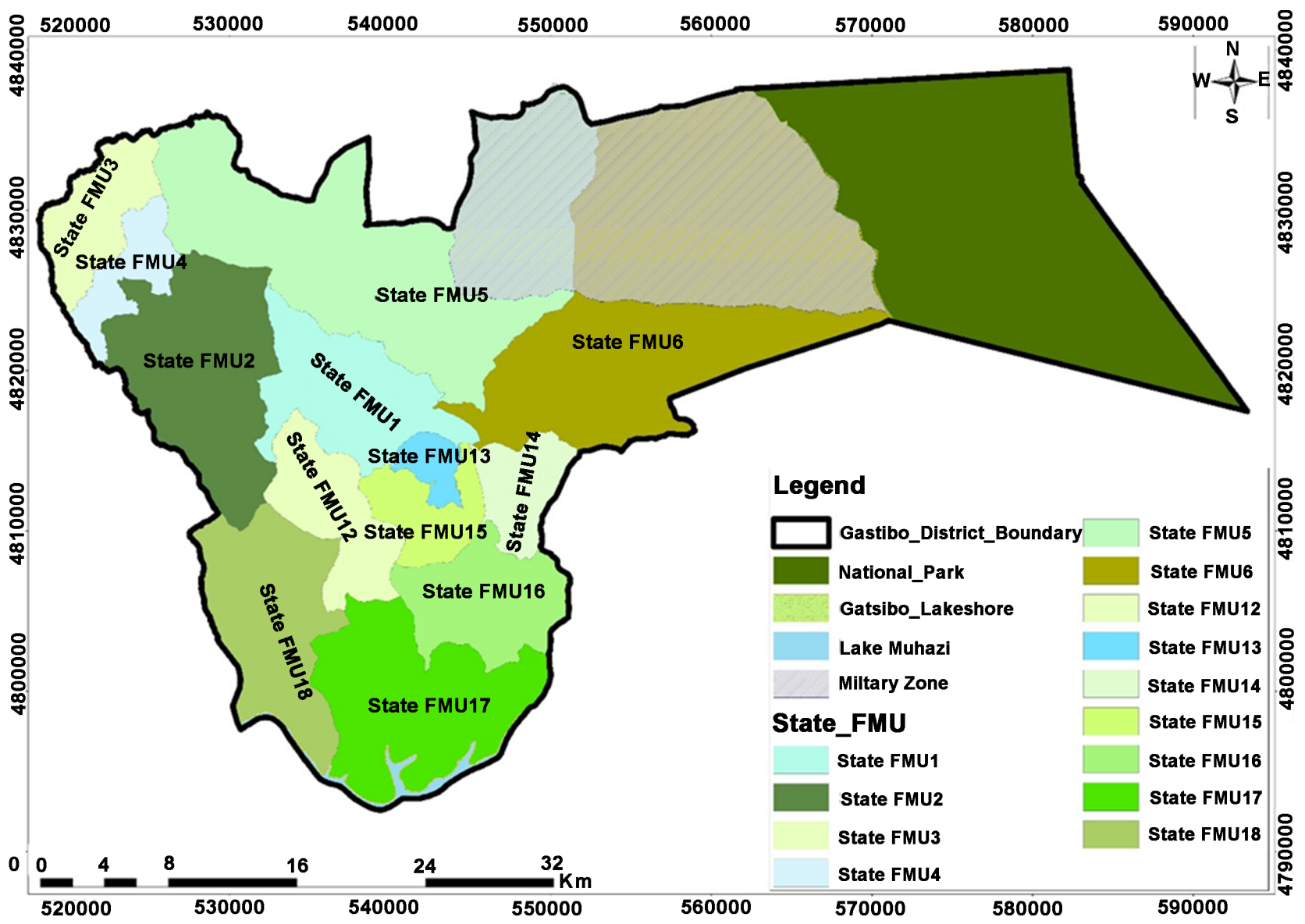

Figure 6. Distribution of state forest management units in gatsibo district.

Table 8. State tenure FMUs with their administrative unsits.

\begin{tabular}{cccc}
\hline & & \multicolumn{2}{c}{ Financial balance (RWF) } \\
\cline { 3 - 3 } District & Scenario & 40 year full rotation cycle & 10 year DFMP period \\
\hline State FMU1 & Scenario 1 & $1,590,707,538$ & $999,991,626$ \\
State FMU1 & Scenario 2 & $862,208,071$ & $680,890,231$ \\
State FMU11 & Scenario 1 & $794,223,384$ & $484,072,694$ \\
State FMU3 & Scenario 1 & $752,933,381$ & $470,161,575$ \\
State FMU4 & Scenario 1 & $726,438,139$ & $465,986,338$ \\
State FMU10 & Scenario 1 & $784,313,047$ & $449,632,889$ \\
State FMU12 & Scenario 1 & $636,060,891$ & $439,036,427$ \\
State FMU14 & Scenario 1 & $828,063,498$ & $429,156,348$ \\
State FMU2 & Scenario 1 & $665,965,832$ & $403,302,473$ \\
State FMU6 & Scenario 1 & $834,463,596$ & $370,271,401$ \\
\hline
\end{tabular}

these forests will in the long term give losses to the investors. It implies that poor management of these forests will incur extra costs to the government making the forest management an expensive and non-profitable venture. 


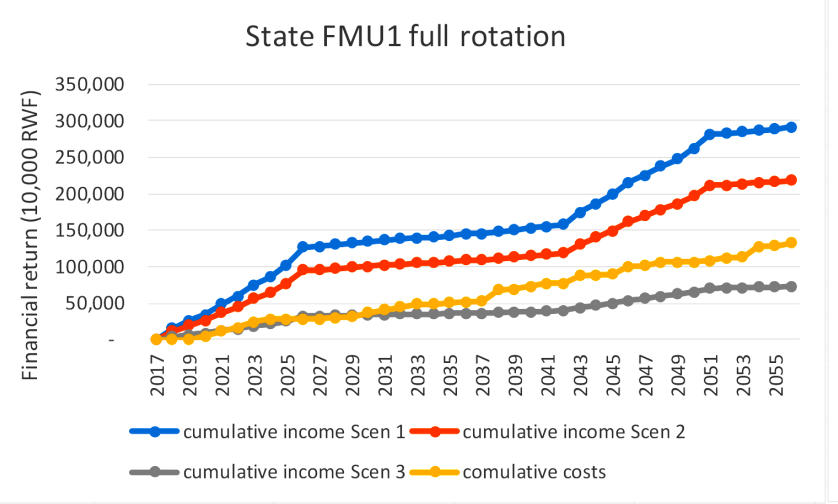

State FMU2 full rotation

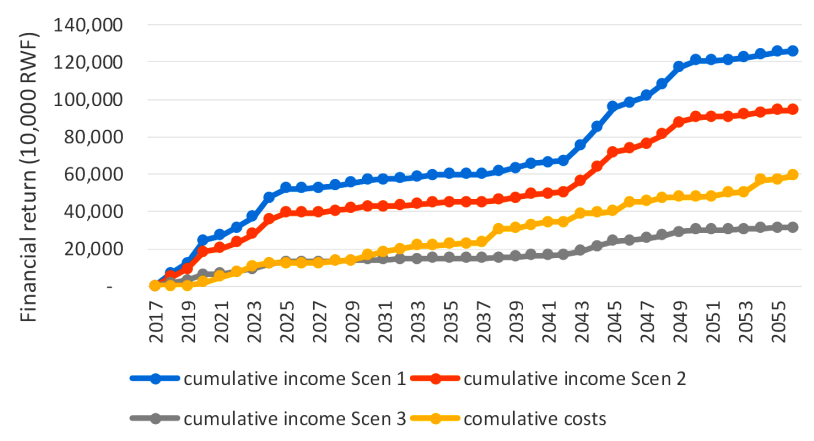

State FMU3 full rotation

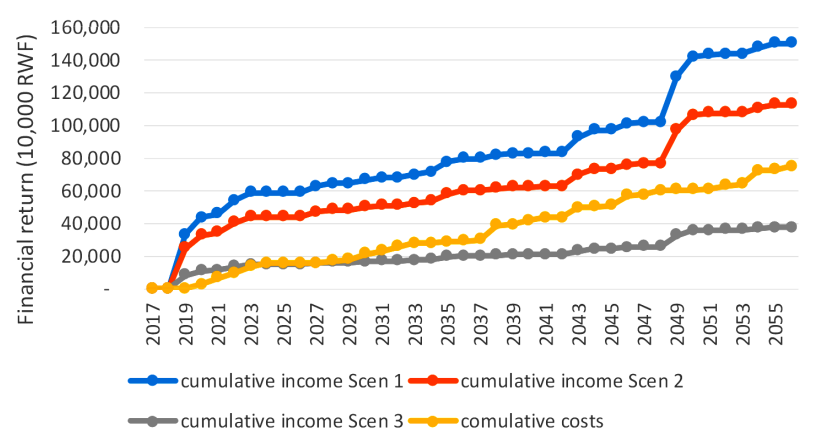

State FMU1 short term plan
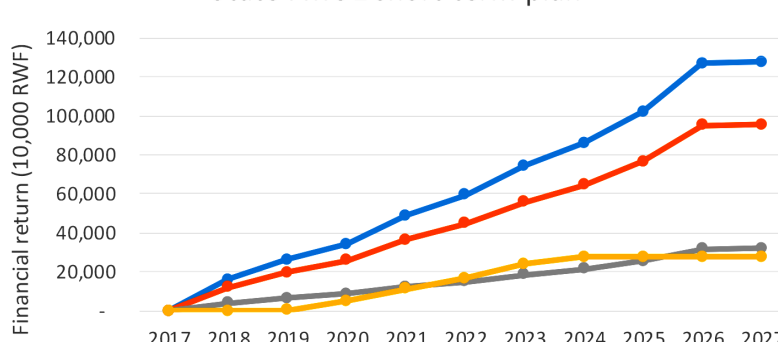

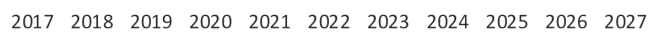
$\longrightarrow$ cumulative income Scen $1 \multimap$ cumulative income Scen 2

$\simeq$ cumulative income Scen $3 \multimap$ comulative costs

State FMU2 short term plan

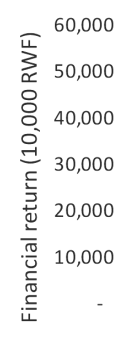

$\begin{array}{lllllllllll}2017 & 2018 & 2019 & 2020 & 2021 & 2022 & 2023 & 2024 & 2025 & 2026 & 2027\end{array}$

$\longrightarrow$ cumulative income Scen $1 \backsim$ cumulative income Scen 2

$\multimap$ cumulative income Scen $3 \multimap$ comulative costs

State FMU3 short term plan

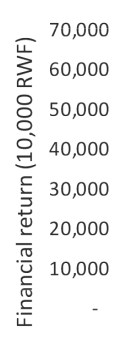

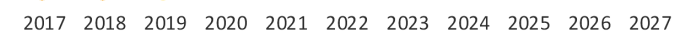

$\longrightarrow$ cumulative income Scen $1 \multimap$ cumulative income Scen 2

$\longrightarrow$ cumulative income Scen $3 \longrightarrow$ comulative costs

Figure 7. An illustration of cumulative incomes and costs for the most viable FMUs.

In two forest management units (District FMU2 and state FMU16), there were positive returns in any of the scenarios in both short term planning and long term planning. This implies that the investor would not recover the costs incurred in rehabilitating the forests even under the best case scenario. There are forests in areas of low productivity and rehabilitation activities targeting such forests should not be based on their financial viability. These forests could be rehabilitated for landscape restoration objectives specifically targeting their ecosystem services (Nichols et al., 2008).

An analysis of the breakeven points for the most viable management units (Figure 7) shows that in the short term planning, the investor will get profit from the three FMUs (state FMU1, state FMU2 and State FMU3) in whichever 

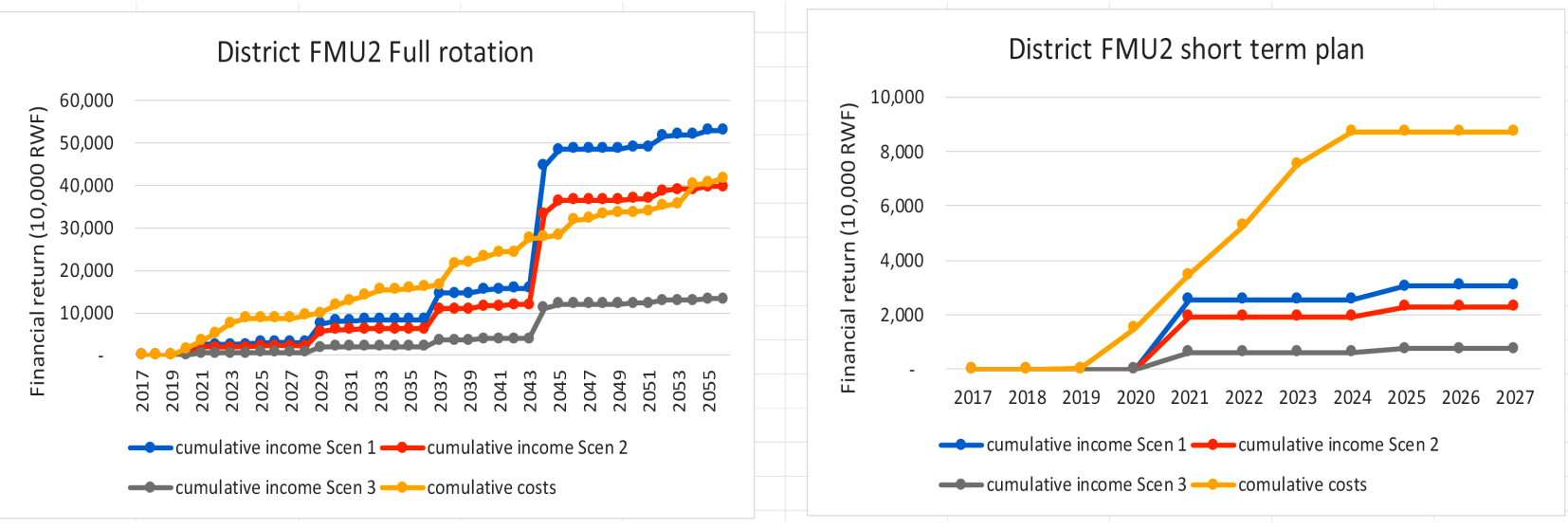

Figure 8. An illustration of cumulative incomes and costs for the most non-viable FMU.

scenario. These are Forests which are mature and once leased, the immediate activity is to harvest before establishing a new crop. In that case sales from the harvests will provide income for the first 10 years even if no management activities are done. However, in the full rotation cycle of 40 years, a poor management of the plantations will not yield profits. The three FMUs are attractive since they illustrate possibilities of clear profits even for the medium case scenario. This is unlike in district FMU2 (Figure 8) where the cost of implementation in the first 10 years is far higher than the returns. The management unit does not provide profits until the year 2043 when only the best case scenario and the real world scenario have incomes surpassing the costs. However these profits are only short lives and by 2055 , the costs of operation are higher than the income from the real world scenario.

These illustrations of the viability of the FMUs are good for the government in determining priorities for leasing out the plantation forests. They also illustrate that forest are not only managed for their income purposes and the case of District FMU2 where no profits are envisaged, the protection of soils and fragile landscapes (MINIRENA, 2014) becomes a priority.

\section{Summary}

The findings of this work show the possibility of exploiting the public plantation forests of Gatsibo district for financial purposes to meet the livelihood requirements derived from wood products and to enhance the family income for communities participating in forest management. The findings illustrate that though the forests of Gatsibo district are poorly stocked, they have a potential to be managed sustainably and continue providing wood products to the current and future generations without compromising their status. The results also show that in some cases, ecosystem benefits of forest rehabilitation may supersede those of commercial purposes.

The findings illustrate that a proper management plan for the forests of Rwanda would enhance their productivity and this would reduce the prevalent 
wood supply and demand gap, noting that a large population of Rwanda's rural communities are largely dependent on wood energy.

\section{Acknowledgements}

This work was actualized under IUCN funding to the Government of Rwanda though the Rwanda Water and Forestry Authority (RWFA) of the Ministry of Natural Resources (MINIRENA). The assignment aimed at supporting the ongoing landscape restoration programme in the eastern province of Rwanda, specifically Gatsibo District. The work is part of the government priorities of managing all forests of Rwanda under a specific management plan. The Inclusive Business and Consultancy Limited (IB \& C) Rwanda provided the consultancy services that mainly included data collection, analysis and writing of the management plan.

\section{References}

Clay, D. C., \& Lewis, L. A. (2017). Land Use, Soil Loss, and Sustainable Agriculture in Rwanda. Case Studies in Human Ecology, 271-287.

Cornelius, J. (1994). Heritabilities and Additive Genetic Coefficients of Variation in Forest Trees. Canadian Journal of Forest Research, 24, 372-379. https://doi.org/10.1139/x94-050

Drigo, R., Munyehirwe, A., Nzabanita, V., \& Munyampundu, A. (2013). Update and Upgrade of WISDOM Rwanda and Woodfuels Value Chain Analysis. Government of Rwanda, MINIRENA.

Fonton, N., \& Weingart, J. B. (2015). Methodology for the Elaboration of Volume Tables for Pine spp., as Well as Eucalypt spp. under Two Silvicultural Regimes. Technical Report No. 1, Rwanda Natural Resources Authority.

GoR (2012). Rwanda Forest Cover Mapping Using High Resolution Aerial Photographs. The Programme d'Appui à la Reforestation PAREF NL/Rwanda Water and Forestry Authority. Government of Rwanda.

GoR (2017). Economic Development and Poverty Reduction Strategy 2013-2018. The Government of Rwanda.

Kinyanjui, J. M. (2009). The Effect of Human Encroachment on Forest Cover, Structure and Composition in the Western Blocks of the Mau Forest Complex. PhD Thesis, Egerton University, Njoro.

MINIRENA (2012). REDD + Readiness Proposal for Rwanda. Ministry of Natural Resources, Government of Rwanda.

MINIRENA (2014). The Ministry of Natural Resources, Rwanda, 2014. Rwanda.

Nichols, E., Spector, J., Louzada, S., Larsen, T., Amezquita, S., \& Favila, M. E. (2008). Ecological Functions and Ecosystem Services Provided by Scarabaeinae Dung Beetles. Biological Conservation, 141, 1461-1474. https://doi.org/10.1016/j.biocon.2008.04.011

Nyirambangutse, B., Zibera, E., Uwizeye, F. K., Nsabimana, D., Bizuru, E., Pleije, H., Uddling, J., \& Wallin, G. (2017). Carbon Stocks and Dynamics at Different Successional Stages in an Afromontane Tropical Forest. Biogeosciences, 14, 1285-1303. https://doi.org/10.5194/bg-14-1285-2017

Randall, B. H. (2007). Forest Management, Developing a Plan to Care for Your Forest. 
Ohio State University Fact Sheet, School of Natural Resources.

Roose, E., \& Ndayizigiye, F. (1997). Agroforestry, Water and Soil Fertility Management to Fight Erosion in Tropical Mountains of Rwanda. Soil Technology, 11, 109-119. https://doi.org/10.1016/S0933-3630(96)00119-5

Sharma, S., \& Henriques, I. (2005). Stakeholder Influences on Sustainability Practices in the Canadian Forest Products Industry. Strategic Management Journal, 26, 159-180 https://doi.org/10.1002/smj.439

Slater, S. F., \& Narver, J. C. (2000). The Positive Effect of a Market Orientation on Business Profitability: A Balanced Replication. Journal of Business Research, 48, 69-73. https://doi.org/10.1016/S0148-2963(98)00077-0

Tahvonen, O., \& Salo, S. (1999). Optimal Forest Rotation with in Situ Preferences. Journal of Environmental Economics and Management, 37, 106-128.

https://doi.org/10.1006/jeem.1998.105 